\title{
Influence of propagules and growth regulators on the performance of underutilized spice - Spiny coriander (Eryngium foetidum L.)
}

\author{
A Samad*, B Singh \& P R Gajurel \\ North Eastern Regional Institute of Science and Technology (Deemed to be University), \\ Nirjuli -791 109, Arunachal Pradesh, India. \\ ${ }^{*}$ E-mail:asamad969@gmail.com
}

Received 07 June 2021; Revised 14 June 2021; Accepted 14 June 2021

\begin{abstract}
An experiment was conducted to study the effect of propagules of spiny coriander (Eryngium foetidum L) as influenced by growth regulators in the Forestry Nursery of North Eastern Regional Institute of Science and Technology during 2018 and 2019. Spiny coriander is an underutilized culinary spice; a medicinal and aromatic plant that belongs to the family Apiaceae. The study consisted of 14 treatments involving two levels of propagules like stem cuttings $\left(\mathrm{S}_{1}\right)$ and suckers $\left(S_{2}\right)$ and seven levels of growth regulators namely Indole Butyric Acid (IBA) and Indole-3 Acetic Acid (IAA) [each at 0,500,1000 and $1500 \mathrm{ppm}$ ]. The results indicated that the treatment $\mathrm{T}_{9}$ involving sucker $\left(\mathrm{S}_{2}+\right.$ IBA $\left.500 \mathrm{ppm}\right)$ was found better in terms of growth and it was comparable with $\mathrm{T}_{12}\left(\mathrm{~S}_{2}\right.$ + IAA 500 ppm) during both years. Suckers treated with IBA 500 ppm and IAA 500 ppm showed significantly superior performance over the stem cuttings. It is concluded that suckers $(7-10 \mathrm{~cm})$ of Eryngium foetidum may be used as propagating material for commercial cultivation, as it is an easy, quick and economical method of propagation.
\end{abstract}

Keywords: growth regulator, stem cutting, sucker

Spiny coriander (Eryngium foetidum L.) is a culinary spice, aromatic and medicinal leafy, underutilized herbal species that belongs to the family Apiaceae. It is known by various common and local names in different languages such as Spiny coriander, Culantro, Bandhonia, Mandhonia (Assamese), Bangladhonia, Bilatidhonia (Bengali) (Singh et al. 2014). It is widely used as spice and condiment for its unique pungent, aroma and essential oil. Mainly used for garnishing, flavouring and seasoning curries, chutneys, sauces, salads and many other dishes. The leaf is also a good source of several nutrients including minerals, vitamins, carotenoids, antioxidants and phytosterols (Ramcharan 1999; Paul et al. 2011; Singh et al. 2013). The aroma gives a characteristic flavour to the dishes and the requirement of this crop is rapidly increasing (Mozumdar et al. 2016).

E. foetidum is usually propagated by seeds, sucker and offshoots, but low germination 
rate, higher price and scarcity of seeds seems a limiting factor for expanding its cultivation of it (Mozumdar et al. 2012). The easiest and most successful method of multiplication of $E$. foetidum is through the vegetative propagation method. Hence, the present experiment was undertaken to study the performance of two propagating materials viz., stem cuttings and suckers of E. foetidum as influenced by growth regulators, so that large scale production of planting materials using low-cost vegetative propagation techniques can be done towards remunerative commercial cultivation of the culinary herb.

The experiment was conducted at the Forestry Nursery of North Eastern Regional Institute of Science and Technology, Nirjuli, Arunachal Pradesh $\left(27^{0} 7^{\prime} 38^{\prime \prime}\right.$ N Latitude and $93^{\circ} 44^{\prime} 19^{\prime /}$ E Longitude at an Altitude of $112 \mathrm{~m}$ from MSL) from September to December 2018 and 2019. The soil texture of the experimental plot was sandy, well-drained with $\mathrm{pH} 5.9$ and organic carbon $0.07 \%$. The initial nutrient status of soil was $0.07 \% \mathrm{~N}, 0.25 \% \mathrm{P}$ and $0.36 \% \mathrm{~K}$. Well rotten farm yard manure at the rate of $5 \mathrm{~kg}$ bed $^{-1}$ was mixed thoroughly at the time of final nursery bed preparation. The average monthly maximum temperature range was $32^{\circ}$ $\mathrm{C}$ (September) to $26.9^{\circ} \mathrm{C}$ (December), whereas the minimum monthly mean temperature ranged from $23.9^{\circ} \mathrm{C}$ (September) to $12^{\circ} \mathrm{C}$ (December) during the experiment period. The highest monthly mean rainfall was recorded from $470.7 \mathrm{~mm}$ (September) to the lowest 18.8 $\mathrm{mm}$ (December), the relative humidity ranged from $86 \%$ (September) to $73.8 \%$ (December) during the experimental period.

The experiment was laid out in factorial Randomized Block Design (RBD) with three replications consisting of 14 treatments involving two Factors; Factor A: Propagules Stem cuttings $\left(\mathrm{S}_{1}\right)$ and Suckers $\left(\mathrm{S}_{2}\right)$, Factor B: Growth regulators namely Indole Butyric Acid (IBA) and Indole-3 Acetic Acid (IAA) - seven levels. The treatment combinations are: $\mathrm{T}_{1}=\mathrm{S}_{1}+$ Distilled water (control), $\mathrm{T}_{2}=\mathrm{S}_{1}+$ IBA 500 ppm, $\mathrm{T}_{3}=\mathrm{S}_{1}+$ IBA $1000 \mathrm{ppm}, \mathrm{T}_{4}=\mathrm{S}_{1}+$ IBA 1500 ppm, $\mathrm{T}_{5}=\mathrm{S}_{1}+$ IAA $500 \mathrm{ppm}, \mathrm{T}_{6}=\mathrm{S}_{1}+$ IAA 1000 ppm, $\mathrm{T}_{7}=\mathrm{S}_{1}+$ IAA $1500 \mathrm{ppm}, \mathrm{T}_{8}=\mathrm{S}_{2}+$ Distilled water (control), $\mathrm{T}_{9}=\mathrm{S}_{2}+$ IBA $500 \mathrm{ppm}, \mathrm{T}_{10}=\mathrm{S}_{2}+$ IBA $1000 \mathrm{ppm}, \mathrm{T}_{11}=\mathrm{S}_{2}+$ IBA $1500 \mathrm{ppm}, \mathrm{T}_{12}=\mathrm{S}_{2}{ }^{+}$ IAA $500 \mathrm{ppm}, \mathrm{T}_{13}=\mathrm{S}_{2}$ + IAA $1000 \mathrm{ppm}$ and $\mathrm{T}_{14}=\mathrm{S}_{2}+\mathrm{IAA} 1500 \mathrm{ppm}$.

Propagating materials of E. foetidum were collected from the Nonpu and Lekha villages of Papum Pare district in Arunachal Pradesh. Propagating materials viz., Stem cuttings of $7-10 \mathrm{~cm}$ length $\left(S_{1}\right)$ and Suckers of 7-10 cm height $\left(S_{2}\right)$ were properly prepared. The basal portions of the propagating materials were properly treated with growth regulators by the quick dip method as per the methodology of Rekha (2008) with suitable modification. Total 672 number of treated propagules were planted on $9^{\text {th }}$ October in properly prepared 42 nursery beds of $1 \mathrm{~m} \times 1 \mathrm{~m}$ size with 16 propagules per bed and plants were harvested on $24^{\text {th }}$ December during both years. Watering was done twice a week throughout the experimental period. Observations were recorded periodically on various shoot and root parameters and data obtained from the experiments were statistically analysed by Fisher's method of Analysis of Variance (ANOVA) (Gomez \& Gomez 1984).

The results revealed that propagules and growth regulators influenced the shooting and rooting significantly. The minimum days taken to first sprout was 15.50 days after planting (DAP) in $\mathrm{T}_{9}$ followed by $\mathrm{T}_{2}(15.67 \mathrm{DAP})$, while the maximum time of 19.83 DAP was observed in $\mathrm{T}_{1}$. It was observed that stem cuttings took more days for the first sprouting. This might be because auxins induce stimulus for regeneration of roots and the suckers performed better than stem cuttings. The maximum number of sprouts per plant was recorded in $\mathrm{T}_{5}(1.95)$ at par with $\mathrm{T}_{2}(1.83)$, against the minimum number of sprouts recorded in $\mathrm{T}_{11}$, $\mathrm{T}_{13}$, followed by $\mathrm{T}_{1}$ (Table 1 ). This might be due to the presence of more nodes on stem cuttings and physiological activities influenced by the growth regulators in cuttings. The maximum length of the sprouted shoot was observed in $\mathrm{T}_{9}(8.45 \mathrm{~cm})$, which are at par with $\mathrm{T}_{12}(7.84 \mathrm{~cm})$, while the minimum shoot length of $3.01 \mathrm{~cm}$ found in $\mathrm{T}_{1}$ (Table 1 ). 
The maximum number of leaves per cutting recorded in $\mathrm{T}_{9}(6.00)$ followed by $\mathrm{T}_{12}$ (5.39) and the minimum number of leaves 3.45 found in $\mathrm{T}_{1}$ (Table 1). This might be due to the initiation of the maximum number of roots in suckers which help in better nutrition and water absorption resulting in a greater number of leaves in $T_{9}$ and $T_{12}$ as compared to $T_{1}$ and $T_{8}$. The highest fresh weight of shoot per plant found in $\mathrm{T}_{9}\left(4.98 \mathrm{~g} \mathrm{plant}^{-1}\right)$, which is at par with $\mathrm{T}_{12}\left(4.86\right.$ g plant $\left.^{-1}\right)$, while the lowest fresh weight of shoot per plant was observed in $T_{1}(0.83 \mathrm{~g}$ plant $^{-1}$ ), coupled with a similar trend of the dry weight of shoots plant ${ }^{-1}$ (Table 1). This might be due to the production of more shoot length and leaves which results in better biomass production in $\mathrm{T}_{9}$ and $\mathrm{T}_{12}$ as compared to $\mathrm{T}_{1}$ and $\mathrm{T}_{8}$. It might be presumed that suckers might have got sufficient food materials as influenced by hormones for induction of root and shoot as compared to stem cuttings. Similar findings were also reported by Kaur and Kaur (2017), Siddiqua et al. (2018) and Kakade et al. (2019). The vigour of the propagules was assessed in terms of number of sprouts plant ${ }^{-1}$, length of the sprouted shoot $(\mathrm{cm})$, number of leaves plant $^{-1}$, number of roots plant ${ }^{-1}$, length of roots (cm) and biomass produced. The biomass productivity of the planting materials under different treatments was assessed in terms of the fresh and dry weight of shoots and roots $\left(\right.$ g plant $\left.^{-1}\right)$.

Significant effects were also observed among different treatments for root parameters. The maximum number of roots per plant was observed in $\mathrm{T}_{9}$ (17.00), followed by $\mathrm{T}_{12}$ (16.17) and $T_{11}$ (16.00), while the lowest number of roots per plant was recorded in $\mathrm{T}_{1}(5.50)$ (Table 2). This might be due to the influence of growth regulators in metabolic activities that help in the initiation of more roots in $T_{9}$ and $T_{12}$ as compared to $T_{1}$. It is well known that hormones regulate different aspects of plant growth and development including cell division, cell elongation and differentiation. Similar findings were also reported by Patel et al. (2017). The longest root was recorded in $\mathrm{T}_{9}(14.07 \mathrm{~cm})$, which is followed by $\mathrm{T}_{10}(12.33$ $\mathrm{cm})$, while the minimum length was observed in $\mathrm{T}_{1}(5.67 \mathrm{~cm})$ (Table 2). It might be due to fact that the application of growth regulators might enhance the formation of callus and differentiation of vascular tissue resulting in elongation of roots in $\mathrm{T}_{9}$ and better performance in suckers as compared to stem cuttings of $E$. foetidum. Maximum fresh weight of roots per plant was recorded in $\mathrm{T}_{9}\left(2.48 \mathrm{~g}_{\text { plant }} \mathrm{t}^{-1}\right)$ which is at par with $\mathrm{T}_{12}\left(2.38 \mathrm{~g} \mathrm{plant}^{-1}\right)$ and $\mathrm{T}_{11}(2.36$ $\left.\mathrm{g} \mathrm{plant}^{-1}\right)$, while the minimum fresh weight of roots per plant was recorded in $T_{1}(0.27 \mathrm{~g}$ plant $\left.^{-1}\right)$, coupled with a similar trend in dry weight of roots per plant (Table 2). This might be due to the formation of a greater number of root biomass along with an increased length of roots in $\mathrm{T}_{9}$ and $\mathrm{T}_{12}$ as compared to $\mathrm{T}_{1}$. Similar results were also reported by Kaur and Kaur (2017), Siddiqua et al. (2018), Kakade et al. (2019).

The percentage of rooting was significantly highest in $T_{9}(91.17 \%)$, followed by $T_{12}$ $(88.75 \%)$, while the lowest rooting percentage was recorded in $\mathrm{T}_{1}(37.09 \%)$ (Table 2). The rooting percentage was observed significantly higher under the treatments of sucker than the stem cuttings. This might be because a lower concentration of IBA 500 ppm and IAA 500 ppm leads to better root formation in suckers than stem cuttings of E. foetidum. A similar result was also observed by Grewal et al. (2005) in chrysanthemum. The highest survival percentage of $88.96 \%$ recorded in $\mathrm{T}_{9}$, which was at par with $\mathrm{T}_{12}(87.09 \%)$, followed by $\mathrm{T}_{13^{\prime}}$ while the lowest survival percentage was observed in $\mathrm{T}_{1}(34.38 \%$ (Table 2$)$. It was found that stem cuttings of E. foetidum survived poorly than the suckers because of a smaller number of roots and leaves produced in stem cuttings. The increase in survival percentage of the suckers with more biomass productivity in $T_{9}, T_{12}$ and $T_{13}$ might be due to profuse rooting and shoot production as influenced by the growth regulators in comparison to stem cuttings. The results are in conformity with Pandey et al. (2011) in stem cuttings of Ginkgo biloba. The poor performance of the stem cuttings might be due to insufficient food materials for the induction of roots and shoots. 
Table 1. Effect of propagules as influenced by growth regulators on the performance of shooting parameters of Eryngium foetidum.

\begin{tabular}{|c|c|c|c|c|c|c|}
\hline Treatments & $\begin{array}{l}\text { Days taken } \\
\text { to first } \\
\text { sprout } \\
\text { (DAP) }\end{array}$ & $\begin{array}{l}\text { Number } \\
\text { of sprouts } \\
\text { plant }^{-1}\end{array}$ & $\begin{array}{l}\text { Length of } \\
\text { sprouted } \\
\text { shoot }(\mathrm{cm})\end{array}$ & $\begin{array}{l}\text { Number } \\
\text { of leaves } \\
\text { plant }^{-1}\end{array}$ & $\begin{array}{l}\text { Fresh } \\
\text { weight of } \\
\text { shoot (g } \\
\text { plant }^{-1} \text { ) }\end{array}$ & $\begin{array}{l}\text { Dry weight } \\
\text { of shoot } \\
\text { (g plant }^{-1} \text { ) }\end{array}$ \\
\hline \multicolumn{7}{|l|}{ Propagules (Factor A) } \\
\hline $\mathrm{S}_{1}$ (Stem cuttings) & 17.64 & 1.45 & 3.68 & 4.03 & 1.68 & 0.45 \\
\hline$S_{2}($ Suckers) & 16.72 & 1.08 & 7.03 & 4.91 & 4.01 & 1.00 \\
\hline CD (0.05) & $0.87^{*}$ & $0.13^{*}$ & $0.44^{*}$ & $0.32^{*}$ & $0.22^{*}$ & $0.03^{*}$ \\
\hline \multicolumn{7}{|c|}{ Growth regulators (Factor B) } \\
\hline Distilled water (Control) & 19.09 & 1.06 & 4.40 & 3.64 & 1.57 & 0.36 \\
\hline IBA 500 ppm & 15.58 & 1.49 & 6.23 & 5.17 & 3.60 & 1.01 \\
\hline IBA 1000 ppm & 17.50 & 1.27 & 5.23 & 4.14 & 2.53 & 0.59 \\
\hline IBA 1500 ppm & 16.58 & 1.14 & 4.89 & 4.11 & 2.85 & 0.72 \\
\hline IAA 500 ppm & 16.25 & 1.54 & 6.14 & 5.06 & 3.62 & 0.93 \\
\hline IAA 1000 ppm & 17.42 & 1.17 & 5.54 & 4.53 & 3.15 & 0.79 \\
\hline IAA 1500 ppm & 17.84 & 1.18 & 5.08 & 4.62 & 2.63 & 0.68 \\
\hline CD (0.05) & $1.61^{*}$ & $0.24^{*}$ & $0.83^{*}$ & $0.59^{*}$ & $0.42^{*}$ & $0.06^{*}$ \\
\hline \multicolumn{7}{|l|}{ Treatments $(\mathrm{A} \times \mathrm{B})$} \\
\hline $\mathrm{T}_{1}\left(\mathrm{~S}_{1}+\right.$ Control $)$ & 19.83 & 1.10 & 3.01 & 3.45 & 0.83 & 0.22 \\
\hline $\mathrm{T}_{2}\left(\mathrm{~S}_{1}+\mathrm{IBA} 500 \mathrm{ppm}\right)$ & 15.67 & 1.83 & 4.00 & 4.34 & 2.21 & 0.64 \\
\hline $\mathrm{T}_{3}\left(\mathrm{~S}_{1}+\mathrm{IBA} 1000 \mathrm{ppm}\right)$ & 18.00 & 1.41 & 3.64 & 3.67 & 0.98 & 0.27 \\
\hline $\mathrm{T}_{4}\left(\mathrm{~S}_{1}+\mathrm{IBA} 1500 \mathrm{ppm}\right)$ & 16.84 & 1.27 & 3.39 & 3.73 & 1.23 & 0.26 \\
\hline $\mathrm{T}_{5}\left(\mathrm{~S}_{1}+\mathrm{IAA} 500 \mathrm{ppm}\right)$ & 17.00 & 1.95 & 4.45 & 4.73 & 2.37 & 0.67 \\
\hline $\mathrm{T}_{6}\left(\mathrm{~S}_{1}+\mathrm{IAA} 1000 \mathrm{ppm}\right)$ & 18.00 & 1.34 & 3.84 & 4.22 & 1.94 & 0.53 \\
\hline $\mathrm{T}_{7}\left(\mathrm{~S}_{1}+\mathrm{IAA} 1500 \mathrm{ppm}\right)$ & 18.17 & 1.27 & 3.45 & 4.06 & 2.14 & 0.55 \\
\hline $\mathrm{T}_{8}\left(\mathrm{~S}_{2}+\right.$ Control $)$ & 18.34 & 1.02 & 5.79 & 3.84 & 2.30 & 0.50 \\
\hline $\mathrm{T}_{9}\left(\mathrm{~S}_{2}+\mathrm{IBA} 500 \mathrm{ppm}\right)$ & 15.50 & 1.16 & 8.45 & 6.00 & 4.98 & 1.39 \\
\hline $\mathrm{T}_{10}\left(\mathrm{~S}_{2}+\mathrm{IBA} 1000 \mathrm{ppm}\right)$ & 17.00 & 1.13 & 6.83 & 4.61 & 4.07 & 0.90 \\
\hline $\mathrm{T}_{11}\left(\mathrm{~S}_{2}+\mathrm{IBA} 1500 \mathrm{ppm}\right)$ & 16.34 & 1.00 & 6.39 & 4.51 & 4.47 & 1.17 \\
\hline $\mathrm{T}_{12}\left(\mathrm{~S}_{2}+\mathrm{IAA} 500 \mathrm{ppm}\right)$ & 15.50 & 1.12 & 7.84 & 5.39 & 4.86 & 1.20 \\
\hline $\mathrm{T}_{13}\left(\mathrm{~S}_{2}+\mathrm{IAA} 1000 \mathrm{ppm}\right)$ & 16.83 & 1.00 & 7.25 & 4.84 & 4.36 & 1.05 \\
\hline $\mathrm{T}_{14}\left(\mathrm{~S}_{2}+\mathrm{IAA} 1500 \mathrm{ppm}\right)$ & 17.50 & 1.09 & 6.72 & 5.17 & 3.13 & 0.81 \\
\hline $\mathrm{S} . \mathrm{Em} \pm$ & 0.27 & 0.05 & 0.30 & 0.13 & 0.23 & 0.06 \\
\hline CD (0.05) & $2.28^{*}$ & $0.34^{*}$ & $1.17^{*}$ & $0.84^{*}$ & $0.59^{*}$ & $0.08^{*}$ \\
\hline
\end{tabular}

* Significant at $\mathrm{P}=0.05$ 
Table 2. Effect of propagules as influenced by growth regulators on the performance of rooting parameters and survival percentage of Eryngium foetidum.

\begin{tabular}{|c|c|c|c|c|c|c|}
\hline Treatment & $\begin{array}{l}\text { Number } \\
\text { of roots } \\
\text { plant }^{-1}\end{array}$ & $\begin{array}{l}\text { Length of } \\
\text { longest } \\
\text { root }(\mathrm{cm})\end{array}$ & $\begin{array}{l}\text { Rooting } \\
\text { percentage } \\
(\%)\end{array}$ & $\begin{array}{l}\text { Fresh weight } \\
\text { of roots } \\
\left(\mathrm{g}_{\text {plant }}{ }^{-1}\right)\end{array}$ & $\begin{array}{l}\text { Dry weight } \\
\text { of roots } \\
\left(\mathrm{g} \text { plant }^{-1}\right)\end{array}$ & $\begin{array}{l}\text { Survival } \\
\text { percentage } \\
(\%)\end{array}$ \\
\hline \multicolumn{7}{|l|}{ Propagules (Factor A) } \\
\hline $\mathrm{S}_{1}$ (Stem cuttings) & 7.14 & 7.03 & 45.69 & 0.37 & 0.10 & 44.40 \\
\hline $\mathrm{S}_{2}$ (Suckers) & 13.93 & 9.35 & 82.74 & 1.93 & 0.37 & 80.47 \\
\hline $\mathrm{CD}(0.05)$ & $0.70^{*}$ & $0.37^{*}$ & $2.72^{*}$ & $0.12^{*}$ & $0.01^{*}$ & $3.16^{*}$ \\
\hline \multicolumn{7}{|c|}{ Growth regulators (Factor B) } \\
\hline Distilled water (Control) & 7.67 & 6.00 & 55.14 & 0.80 & 0.16 & 51.44 \\
\hline IBA 500 ppm & 12.75 & 10.78 & 72.56 & 1.45 & 0.29 & 70.42 \\
\hline IBA 1000 ppm & 10.42 & 9.50 & 60.00 & 1.15 & 0.24 & 58.44 \\
\hline IBA 1500 ppm & 10.92 & 7.46 & 61.46 & 1.32 & 0.26 & 60.72 \\
\hline IAA 500 ppm & 12.83 & 8.89 & 70.43 & 1.50 & 0.30 & 68.54 \\
\hline IAA 1000 ppm & 9.84 & 7.29 & 65.01 & 1.03 & 0.22 & 63.54 \\
\hline IAA 1500 ppm & 9.34 & 7.44 & 64.90 & 0.82 & 0.18 & 63.96 \\
\hline $\mathrm{CD}(0.05)$ & $1.28^{*}$ & $0.70^{*}$ & $5.09^{*}$ & $0.22^{*}$ & $0.04^{*}$ & $5.90^{*}$ \\
\hline \multicolumn{7}{|l|}{ Treatments $(\mathrm{A}$ x B) } \\
\hline $\mathrm{T}_{1}\left(\mathrm{~S}_{1}+\right.$ Control $)$ & 5.50 & 5.67 & 37.09 & 0.27 & 0.07 & 34.38 \\
\hline $\mathrm{T}_{2}\left(\mathrm{~S}_{1}+\mathrm{IBA} 500 \mathrm{ppm}\right)$ & 8.50 & 7.50 & 53.96 & 0.42 & 0.12 & 51.88 \\
\hline $\mathrm{T}_{3}\left(\mathrm{~S}_{1}+\mathrm{IBA} 1000 \mathrm{ppm}\right)$ & 6.67 & 6.67 & 41.05 & 0.33 & 0.09 & 40.00 \\
\hline $\mathrm{T}_{4}\left(\mathrm{~S}_{1}+\mathrm{IBA} 1500 \mathrm{ppm}\right)$ & 5.84 & 7.19 & 43.13 & 0.29 & 0.07 & 42.71 \\
\hline $\mathrm{T}_{5}\left(\mathrm{~S}_{1}+\mathrm{IAA} 500 \mathrm{ppm}\right)$ & 9.50 & 8.17 & 52.08 & 0.61 & 0.16 & 50.00 \\
\hline $\mathrm{T}_{6}\left(\mathrm{~S}_{1}+\mathrm{IAA} 1000 \mathrm{ppm}\right)$ & 6.17 & 7.06 & 45.21 & 0.30 & 0.08 & 44.58 \\
\hline $\mathrm{T}_{7}\left(\mathrm{~S}_{1}+\mathrm{IAA} 1500 \mathrm{ppm}\right)$ & 7.84 & 7.02 & 47.30 & 0.40 & 0.12 & 47.30 \\
\hline $\mathrm{T}_{8}\left(\mathrm{~S}_{2}+\right.$ Control $)$ & 9.83 & 6.34 & 73.21 & 1.34 & 0.25 & 68.50 \\
\hline $\mathrm{T}_{9}\left(\mathrm{~S}_{2}+\mathrm{IBA} 500 \mathrm{ppm}\right)$ & 17.00 & 14.07 & 91.17 & 2.48 & 0.46 & 88.96 \\
\hline $\mathrm{T}_{10}\left(\mathrm{~S}_{2}+\mathrm{IBA} 1000 \mathrm{ppm}\right)$ & 14.17 & 12.33 & 78.96 & 1.96 & 0.39 & 76.88 \\
\hline $\mathrm{T}_{11}\left(\mathrm{~S}_{2}+\mathrm{IBA} 1500 \mathrm{ppm}\right)$ & 16.00 & 7.73 & 79.79 & 2.36 & 0.45 & 78.75 \\
\hline $\mathrm{T}_{12}\left(\mathrm{~S}_{2}+\mathrm{IAA} 500 \mathrm{ppm}\right)$ & 16.17 & 9.60 & 88.75 & 2.38 & 0.44 & 87.09 \\
\hline $\mathrm{T}_{13}\left(\mathrm{~S}_{2}+\mathrm{IAA} 1000 \mathrm{ppm}\right)$ & 13.50 & 7.52 & 84.80 & 1.76 & 0.37 & 82.50 \\
\hline $\mathrm{T}_{14}\left(\mathrm{~S}_{2}+\mathrm{IAA} 1500 \mathrm{ppm}\right)$ & 10.83 & 7.85 & 82.50 & 1.24 & 0.23 & 80.63 \\
\hline S.Em \pm & 0.64 & 0.36 & 3.08 & 0.14 & 0.02 & 3.04 \\
\hline $\mathrm{CD}(0.05)$ & $1.82^{*}$ & $0.98^{*}$ & $7.21^{*}$ & $0.32^{*}$ & $0.06^{*}$ & $8.34^{*}$ \\
\hline
\end{tabular}

* Significant at $\mathrm{P}=0.05$ 
It was observed that among the treatments, suckers treated with IBA $500 \mathrm{ppm}$ and IAA 500 ppm showed comparatively better results than stem cuttings for shooting and rooting parameters. Based on the findings of the present experiment, it can inferred that vegetative method of propagation by suckers of spiny coriander was significantly promising and reliable. From the study, it can be concluded that $7-10 \mathrm{~cm}$ height suckers treated with IBA 500 ppm or IAA 500 ppm is a successful technique in generating, planting material, as it is an easy, quick and economical method of propagation.

\section{References}

Grewal H S, Kumar S \& Chauhan R 2005 Effect of IBA and NAA on rooting of chrysanthemum (Dendranthema grandiflora) terminal cuttings, J. Ornamental Horti. 8: 230-232.

Gomez K A \& Gomez AA 1984 Statistical Procedures for Agricultural Research (2 ${ }^{\text {nd }}$ Edn.), John Wiley \& Sons Inc, New York.

Kakade V, Dinesh D, Singh D, Bhatnagar P R \& Kadam D 2019 Influence of length of cutting onroot and shoot growth in dragon fruit (Hylocereus undatus). Ind. J. Agric. Sci. $\quad$ 89: 1895-1899.

Kaur A \& Kaur A 2017 Effect of IBA concentrations on success of cuttings of fig cv. Brown turkey. Int. J. Sci. Res. 8: 1576-1579.

Mozumdar S N, Rahman M M, Hossain M M, Ahmed J U \& Khan M A A 2012 Effect of row and plant spacing on seed production of Eryngium foetidum. Int. J. Horti. 2:13-20

Mozumdar S N, Hossain M M \& Akter S 2016 Influence of seed treatment and priming on growth performance of Eryngium foetidum. Int. J. Adv. Res. In Biol. Sci. 3: 113-122.
Paul J H, Seaforth C E \& Tikasingh T 2011 Eryngium foetidum L.: a review. Fitoterapia. 82: 302-308.

Pandey A, Sushma T \& Dinesh G 2011 Role of auxin on adventitious root formation and subsequent growth of cutting raised plantlets of Ginkgo biloba L. Int. J. Biodiv. \& Conservn. 3: 142-146.

Patel H R, Patel M G \& Singh S 2017 Effect of different levels IBA and NAA on rooting of hardwood and semi hardwood cutting in fig. J. Agric. Sci. Res. 7: 519-523.

Ramcharan C 1999 Culantro: A much utilized, little understood herb. In: Janick, J. (ed), Perspectives on new crops and new uses. ASHS Press, Alexandria, pp. 506-509.

Rekha K M 2008 Standardization of vegetative propagation of stevia (Stevia rebaudiana Bertoni) through stem cuttings using growth regulators, M.Sc. (Horti.) Thesis, University of Agricultural Sciences, Bangalore.

Siddiqua A, Thippesha D, Shivakumar B S, Adivappar N \& Ganapathi M 2018 Effect of growth regulators on rooting and shooting of stem cuttings in dragon fruit [Hylocereus undatus (Haworth) Britton \& rose], J. Pharmacog. \& Phytochem. 7: 1595-1598.

Singh S, Singh D R, Banu K M \& Salim K M 2013 Determination of bioactives and antioxidant activity in Eryngium foetidum L.: a traditional culinary and medicinal herb. Proc. Natl. Acad. Sci. India, Sec B Biol. Sci. 83: 453-460.

Singh B K, Ramakrishna Y \& Ngachan S V 2014 Spiny coriander (Eryngium foetidum L.): a commonly used, neglected spicing-culinary herb of Mizoram, India. Genet. Resour. Crop. Evol., Springer, DOI 10.1007/s10722-0140130-5. 